\title{
A 'Fool' and His Sugar-Sweetened Beverage are Soon Taxed
}

\author{
Bret N. Bogenschneider ${ }^{1}$
}

Published online: 25 March 2017

(C) The Author(s) 2017. This article is an open access publication

\begin{abstract}
Tax policy informed by Libertarian paternalism suggests that taxes should be levied on non-'rational' choice (i.e., where a person makes a 'foolish' decision by their own internal standards). In respect of excise taxes on sugar sweetened beverages, the regressivity of such policies can then be justified by reference to a progressive health effect, since the poor are more sensitive to changes in price and disproportionately tend to consume sugar sweetened beverages. However, as it currently stands, that conclusion is based merely on a presumption of irrationality of the poor as a class and neither the relative price of goods subject to such taxes, nor the associated 'welfare loss' from the levy of the tax, have been systematically measured. Such a presumption of non- 'rationality' in food choice only holds with respect to persons who are not bound by relative prices of food, namely the wealthy. Accordingly, it is reasonable for scholars to consider the levy of excise taxes on unhealthy food consumed primarily by the wealthy (e.g., foie gras) as a 'nudge' toward a healthier food choice. Furthermore, the poor are rational agents capable of analysing and comparing relative prices of food products taking into account the health effects. As various scholars have now proposed in medical journals, any incremental tax levied on the poor in respect of sugar-sweetened beverages should be offset, for example, with a credit for healthy foods including fruits and vegetables.
\end{abstract}

Keywords Libertarian paternalism · Internality · Pigouvian tax · Psychologism · Rational choice theory $\cdot$ Sugar sweetened beverage $\cdot$ Taxation

Bret N. Bogenschneider

b.bogenschneider@surrey.ac.uk

1 Finance Law and Ethics, School of Law, University of Surrey, Guildford, UK 


\section{Introduction}

Obesity is the disease and taxes levied on sugar-sweetened beverages are the treatment for it—so says Kelly Brownell. ${ }^{1}$ Such tax policy 'therapy' for obesity is not so much a 'nudge' as the Libertarian paternalists Richard Thaler and Cass Sunstein have in mind, ${ }^{2}$ but a more direct form of paternalism where consumer choices are presumed to be non-'rational' in many cases. Brownell accordingly wrote at one point that thirsty people should be encouraged to just drink water. ${ }^{3}$ The New York Times printed a similarly blunt assessment of food choice: 'It is evident that some people just aren't responsible enough to feed themselves. ${ }^{4}$ And, this assessment builds on the purportedly 'libertarian' view of Thaler and Sunstein who wrote: 'The presumption that individual choices should be free from interference is usually based on the assumption that people do a good job of making choices, or at least that they do a far better job than third parties could do. As far as we can tell, there is little empirical support for this claim.' ${ }^{5}$ The result is that consumer food choices can then be described as broadly non- 'rational' meaning not in accordance with an individual's own preferences, which for the reasons explained in detail here has major implications for tax policy design.

The regressivity of sin taxes is often presumed to have a progressive health effect sufficient to offset the negative aspects of regressivity. ${ }^{6}$ Some empirical evidence has been given to support the claim by reference to the price elasticity of food demand where socioeconomic status is found to be significant in similar contexts of consumer choice $^{7}$; albeit no significant evidence has ever been developed on the underlying consumer preferences, or what is referred to in economic terms as consumer 'welfare'. This is important because taxes, especially regressive taxes, are presumed by standard economic theory to reduce the 'welfare' of the payor. If taxes are instead presumed to be beneficial to the payor, then the tax should be maximized thus resulting in a de facto prohibition by taxation.

One immediate problem is that the presumption of non-'rationality' in food choice only holds with respect to persons who are not bound by the relative prices of food. Indeed, if one truly believes that sin taxes are broadly beneficial for classes of persons engaged in non-'rational' eating behaviour, the only persons we know for sure are behaving in such a non-'rational' manner are the wealthy (who are not

\footnotetext{
${ }^{1}$ Brownell et al. (2009), Brownell and Novak (2011), Franck et al. (2013) but see Shughart, ed. (1997), Rizzo and Whitman (2009).

2 Thaler and Sunstein (2003a, b), see also Schiavone et al. (2014); Amir and Lobel (2008).

3 Brownell et al. (2009), 1604 ('[A] tax that shifted intake from sugar-sweetened beverages to water would benefit the poor both by improving health and by lowering expenditures on beverages. Designating revenues for programs promoting childhood nutrition, obesity prevention, or health care for the uninsured would preferentially help those most in need').

4 Neistat (2012) ('A New York-based filmmaker wrote that 'it is evident that some people just aren't responsible enough to feed themselves.' cited in Min (2013).

5 Thaler and Sunstein (2003a, b), 176.

6 See Brownell and Frieden (2009), Chaloupka (2009), but see Corneslen et al. (2015).

7 See Bogenschneider (2017) citing Wandel (1997).
} 
bound by price of foods, by definition). To say anything about the rationality of the poor, who are bound by the relative price of foods, we would require empirical data on both relative prices and consumer food preferences. ${ }^{8}$ Accordingly, in the absence of empirical data on consumer welfare, what we can coherently say in scientific terms is that sin taxes should instead be levied on the food choices of the wealthy which are not decisions subject to bounds in respect of price and could benefit by definition from a 'nudge' toward a healthier option. Nonetheless, current tax policy seems to be moving in the opposite direction toward the taxation of foods and other products used predominantly by the poor as a class.

The key difference between tax policy derived by Brownell, et al. in respect of sugar sweetened beverages and prior tax policy is the presumption that taxes are beneficial to the persons required to pay those taxes. Simply put, Brownell, et al., have switched the philosophical premise that taxes, especially regressive taxes, are harmful to consumers. If taxes have such a beneficial and progressive health effect, then sin-taxes should be maximized to increase the welfare of such non-'rational' persons. Obviously, in the case that taxes increase individual welfare, such taxes should be increased especially on 'fools' and other irrational persons who stand to gain from incremental taxation, particularly poor persons as a class. And, as public health experts insist, there must be a progressive health effect of taxation for those persons who have the most to gain, namely the poor. Of course, such a claim hinges on the coherency and workability of the definition of non-'rational' consumer choice as proposed by Thaler and Sunstein.

\section{Libertarian Paternalism and Tax Policy}

Libertarian paternalism suggests that taxes should be levied on non-rational behaviour, where the term 'rational' typically is defined by economic theory (which technically relates to each person's own individuals preferences). The tax is thus ostensibly levied based on a non-rational choice, but crucially not levied simply for being obese. Muireann Quigley applied the economic rationale to health policy policies, as follows:

There are... situations in which preventing people from making 'stupid decisions' could be seen as a legitimate sphere of action for government and regulators... Take for example unhealthy eating habits; say a person with a continuous diet high in refined sugar and saturated fats. These may impact on those around them; their family and friends if they become ill and, more importantly in the context of the discussion here, the state in terms of the cost of health care or work days lost. ${ }^{9}$

Taxes so designed to offset economic 'externalities' (i.e., costs imposed on other persons) are referred to as Pigouvian taxes, ${ }^{10}$ where gasoline taxes are often held out

\footnotetext{
${ }^{8}$ See Finkelstein et al. (2010).

9 Quigley (2013).

10 Masur and Posner, 95 ('A Pigouvian tax is a tax equal to the harm that the firm imposes on third parties') citing Sandmo (1976).
} 
as the prime example. ${ }^{11}$ However, with respect to obesity and taxes, the tax policy issue relates in significant part to 'internalities' (i.e., not externalities), where the consumer fails to take into account health costs to their own person from a consumption choice. ${ }^{12}$ The discourse over tax policy is accordingly given along the lines of Pigouvian-type taxes except insofar as the harm is here an internal harm to the self. ${ }^{13}$

The distinction between internal versus external harm is important because in the case of taxation premised on an internalized harm to personal health, the taxed person potentially ends up both paying the Pigouvian-type tax and also suffering the personal harm that the tax was designed to address. ${ }^{14}$ In the analogous situation of a Pigouvian tax on an externality, the taxed person is obviously not the person that also suffers the external harm. The regulation of 'internalities' is thus rightly taken as paternalistic where the subject of the regulation essentially fails to properly assess personal costs in the decision to consume unhealthy food, such as sugar-sweetened beverages. ${ }^{15}$ Riccardo Rebonato addresses the issue in Coasean terms as negotiation between one's current and future self over health internalities: '[F]or many individuals going about their lives consistently listening to what their rational selves suggest entails psychological costs they would not be prepared to pay. ${ }^{16}$ Libertarian paternalism proposes a justification for government regulation of an adult who fails to behave properly by their own standards. Camerer, et al., pejoratively refers to this as 'idiotic' economic behaviour. ${ }^{17}$ This paper proposes that consumers do make rational decisions despite significant barriers and limited bounds of possible decisions for the poor.

\section{The Limits of Libertarian Paternalism}

Robert Baldwin has optimistically described Thaler and Sunstein's proposal of 'Libertarian paternalism' as a new type of 'philosophy'. ${ }^{18}$ Several scholars also predictably conclude that Thaler and Sunstein did not give a proposal reflective of Libertarian philosophy. ${ }^{19}$ The words 'libertarian' and 'paternalism' so combined is akin to saying 'altruistic utilitarian' or 'social Nietzschean'. Notably, the latter oxymoron (by citing Nietzsche for social values) spawned an extensive responsive

\footnotetext{
11 See Mankiw (2009), 15; but see Masur and Posner, 108.

12 Herrnstein, et al. (1993).

13 See Masur and Posner (2015), but see Fleischer, (2015).

14 Strnad (2005, 1254) ('Imposing a tax in that amount means that the consumer will pay the same costs twice: the first time as a tax and the second time in the form of actual internal costs such as ill health'); but see Pomeranz (2012/13), 1004 ('[S] uch a tax would persistently and negatively impact those of low economic status. They would be doubly penalized for being poor: first because they do not have the resources to eat as well as the wealthy and second because a person of wealth could afford to be overweight or have diabetes and pay the tax').

15 Rizzo and Whitman, 707.

16 Rebonato, 376.

17 Camerer (2003).

18 Baldwin (2014).

19 Quigley, 606 ('First, nudges are neither libertarian nor paternalistic as is claimed').
} 
literature in law journals, which now refers to the patently wrong application of philosophical ideas as 'intellectual voyeurism'. ${ }^{20}$ So, the more critical response to the idea of 'Libertarian Paternalism' is simply to say that it is a wrong usage of words; for example, the analysis is based on several possible mistakes of facts in respect of describing economic choices. Another possible response to Libertarian paternalism is to orient it within philosophy. In that respect, the 'ought' versus 'is' framework of personal choice is psychologism (as extensively debated by German philosophers in the late Nineteenth century). ${ }^{21}$ The 'ought' versus 'is' framework was also famously applied to the law by Hans Kelsen in what he referred to as 'normative' legal analysis. ${ }^{22}$ The link between economic theory and forgotten lines of philosophical thought is discussed in more detail below.

In economic terms, Libertarian paternalism is an attempted extension of the field of Behavioural Economics in a 'softer' form with some deference given to individual preferences in respect of choice. ${ }^{23}$ Behavioural economics as a field of study arose in in the $1950 \mathrm{~s}$ in response to objections to 'rational choice' of neoclassical economic theory as not corresponding very well to actual human behaviour. $^{24}$ Herbert Simon proposed using traditional economic analysis to develop 'approximate' ideas of rationality to better reflect the actual decisions of human beings. ${ }^{25}$ The origin of behavioural economics reflects to some extent an internal dispute within the field of economics over the key issue of whether all economic behavior is rational enough to be studied as if it were rational ${ }^{26}$; or, to put it differently, whether all economic behaviour is economic-enough to be studied as if it were economic. ${ }^{27}$ Camerer, et al., accordingly defined behavioural economics as extending the normal bounds of 'rationality' in the eyes of economists ${ }^{28}$ while still 'maintaining the emphasis on rigor and field applications that sets economics

\footnotetext{
${ }^{20}$ Leiter (1992).

21 See Green (1999).

22 See Kelsen (1962), 79 ('The rule of law remains objective description; it does not become prescription').

23 Yeung, 134 ('Soft paternalism involves intervention to prevent an agent from doing X, where the paternalist judges that, relative to the agent's own views of his or her self-interest, the doing of $\mathrm{X}$ is not in the agent's interests').
}

24 See Becker (1962), Becker (1990), Thaler (1991), see also Yeung, 128 ('Behavioural law and economics. The findings of experimental cognitive psychologists identifying these and other systematic decision-making flaws have been seized upon by economists, generating a body of work which has become known as 'behavioural economics' and its offspring 'behavioural law and economics' (or the 'new law and economics'). Unlike orthodox law and economics methodology, new law and economics seeks to challenge the standard economic model by pointing to systematic divergences from the premise of the rational self-interested decision-maker that orthodox economic modelling takes as its starting point').

25 Simon (1983), see also Sen (1977).

26 Rostain, 978.

27 Cooter and Ulen (2012), 3 ('Economics generally provides a behavioral theory to predict how people respond to laws. This theory surpasses intuition just as science surpasses common sense').

28 Rizzo and Whitman (2009), 686 ('The new paternalism is supported by a growing body of research in behavioral economics showing that individuals are not fully 'rational,' as economists understand that term, but instead are subject to a variety of cognitive errors and biases'). 
apart from other social sciences. ${ }^{29}$ Hence, the approach amounts to 'economic behaviourism' (i.e., distinguishable from the inverse: Behavioural Economics) reflecting the use of 'rigorous' economic methods where 'behaviourism' is generally taken as comprising the social sciences and psychology. The compromise accordingly gave rise to new hybrid fields of economics combined with something else, such as economic psychology. Such 'economic-behaviourism' acknowledges the possibility of non-economic frameworks of decision as opposed to the denial of the validity of 'non-rational' methods of choice. In any case, the word 'rational' refers to the neoclassical economic study of human decisions in economic terms; thus, 'non-rational' refers to evaluating human decisions under any other framework. This explains why hybrid fields including economic psychology are seen by some economists as the 'rigorous' study of non-rational modes of decisionmaking.

As illustrated in the prior paragraph, the term 'rational' is defined by economists in a positivistic sense as economics itself. So, where a decision is inconsistent with economic theory, it can be described as irrational. Thomas Ulen defines 'economics' in positive terms as the rational analysis of human behavior. ${ }^{30}$ Ulen's positive definition can be restated as follows:

Economics is the study of human behavior that is admittedly not always ['rational'], but is thought to be [rational] enough in the aggregate that it can be studied as if it were [rational].

The word-order can be further re-arranged to yield the following helpful result:

Economics is the study of human behavior that is admittedly not always ['economic']...

This type of definitional positivism is what Richard Posner meant in his reference to a 'rational frog', 31 defined as simply a frog that acts consistently with what economists would expect for frogs and not as a claim as to the rationality of the frog itself. Posner writes:

The basic assumption [of economics], that human behavior is rational, seems contradicted by the experiences and observations of everyday life. The contradiction is less acute when one understands that the concept of rationality used by the economist is objective rather than subjective, so that it would not be a solecism to speak of a rational frog. ${ }^{32}$

\footnotetext{
${ }^{29}$ Camerer et al. 1215.

${ }^{30}$ Ulen (1999), 790; see also Posner (2003), 17 ('[R]ationality is the ability and inclination to use instrumental reasoning to get on in life'); Cooter and Ulen, 18 ('Indeed, some economists believe that the conditions they impose on the ordering or ranking of consumer preferences constitute what an economist means by the term rational').

31 Posner (2003).

32 Posner (2003), 17.
} 
Hence, it is not coherent to say that some persons are economic 'idiots' as a matter of neoclassical economic theory without exploring differences in individual preferences. ${ }^{33}$ For this reason, Camerer, et al., qualify their position that the Libertarian paternalist approach ought to apply to situations rather than persons. However, Camerer, et al. then paradoxically proceeds to speak in respect of 'idiotic' persons. If the objective was to regulate situations, the economic proposals ought to be along the lines of reducing difficult or confusing financial situations that low-income persons face on a daily basis, such as arcane tax rules (the quintessential example of which is the earned income tax credit eligibility test in the United States). Yet, Camerer, et al., propose nothing of the sort. Their focus is instead on the 'bad' decisions of poor persons as a class, thus distinguishable from the wealthy who are able to make 'good' economic choices that are by definition rational.

The economic proposal to tax 'fools' for purportedly 'irrational' behaviour (such as in the purchase of sugar-sweetened beverages) is partly a proposal to tax persons who do not think as economists think or choose as economists choose. In the practical terms of Libertarian paternalism, 'irrational' behavior becomes all nonneoclassical economic versions of choice. Any proposal to levy a tax on irrational 'idiots' who choose to drink sugar-sweetened beverages thus represents a proposal for a tax on persons who did not make the 'correct' economic choice. The idea is to levy a tax on persons that do not conform to the economic ideology of rational choice! ${ }^{34}$ And, if Thaler and Sunstein are to be believed, this failure applies to most persons most of the time. However, among other problems, the expectations of behavioural economics are based on a probabilistic assessment of what economic behavior is expected to be in the population as a whole which may not apply to any one individual. ${ }^{35}$

Libertarian paternalism can also be described as a simple 'ought'-based claim for social engineering toward homo economicus. ${ }^{36}$ For example, no attempt has been made to quantify the 'welfare loss' to persons from the taxation of sugar-sweetened beverages. ${ }^{37}$ This explains why economists do not proceed to draw utility functions in respect of sugar-sweetened-beverage tax proposals. Such functions would tend to disprove the normative economic argument that persons are not making a rational

\footnotetext{
33 Baldwin, 850 ('[P]ro-nudgers are too quick to portray some preferences as irrationalities. Thus, some of the 'biases and blunders' that Thaler and Sunstein cite as causes of poor decisions can be said to be preferences that deserve to be respected rather than cognitive or volitional failings that need to be reacted to with a nudge').

34 Yeung, 128 ('[Libertarian paternalism identifies] fallible individuals who have inescapable difficulties in making decisions that conform to the rational actor model').

35 Veetil (2011), 332 ('Also, if individuals sometimes make inoptimal decisions for themselves in the 'private sphere' then they are even more likely to make inoptimal decisions in the 'public sphere', ie, electing the government (planners). Buchanan (1954) in a paper titled "Individual Choice in Voting and Market" discusses the sources of deficiencies in the "process of electing planners" as compared to the 'process of choice in a market with monetary prices').

36 Rostain (2000).

37 See Dolgin and Dieterich (2011), 1126.
} 
consumption choice with respect to sugar-sweetened beverages. ${ }^{38}$ In lay terms, one might just say the normative economic claim regarding sugar- sweetened beverages is not a very good explanation of human behavior. The explanation does not take into account why or how much the regulated person values the sugar-sweetened beverage because losing the beverage is to lose that welfare. ${ }^{39}$

Likewise, the tax policy proposals in respect of sugar-sweetened beverages are incomplete because the Pigouvian tax does not offset an externality. The tax potentially increases the harm to the affected person. As an illustration, Brownell, et al., propose to first levy a tax, and then to use the tax proceeds to achieve the desired causal result. The desired policy outcome depends on the expenditure made possible by the tax and not the tax itself. A similar tax policy result could be achieved by levying a tax on the income of the wealthy and using it for nutritional expenditure programs. ${ }^{40}$ The levy of incremental tax on low income persons will partly tend toward making an economic situation worse for those low income persons who are already subject to extraordinarily high effective tax rates. ${ }^{41}$ As an example, for women in the United States where excellent data is available, socioeconomic status is highly correlated with obesity. ${ }^{42}$ Yet, it is solely in the circumstances where the wealthy are taxed that economists acknowledge, perhaps even set out to quantify, the various welfare losses of taxation.

The relative worsening of socioeconomic status by incremental taxation will likely yield a host of nasty results including to public health outcomes and obesity rates. ${ }^{43}$ Any policy analysis of a regressive tax proposal requires consideration of the costs and benefits, not just the benefits. ${ }^{44}$ The common description of regressive taxation as a 'fairness' issue, as opposed to a causal issue is incomplete. ${ }^{45}$ The approach depends on misapplying economic theory as a normative argument rather than as a scientific method (i.e., identifying only one-half the policy analysis relating to either costs or benefits). An extensive literature already exists on the unfairness of regressive excise taxes designed to limit consumer choice; however,

\footnotetext{
38 Baldwin, 846 ('A further concern of nudge's critics may be that the banner of libertarian paternalism may be used as a cover for the pursuit of social objectives (such as lowering hospitals' administration costs) rather than the welfare of the nudged individuals').

39 Pratt, 128 ('If consumers avoid the tax by buying less-preferred, untaxed goods, instead of the taxed goods that they prefer, and no revenue is raised, this substitution could cause a welfare loss').

40 Strnad, 1225 ('Tying junk food taxes to health-initiative expenditures may create political appeal, but from a normative standpoint the justification for connecting the tax and the expenditures is not clear. If nutrition education has high public value, the government should be willing to fund these activities through revenues raised from the most efficient source').

41 For a calculation of effective tax rates by income level see: Bogenschneider, (2014).

42 Ogden, et al. (2010), 2 ('Among women, obesity prevalence increases as income decreases. Overall, $29.0 \%$ of women who live in households with income at or above $350 \%$ of the poverty level are obese and $42.0 \%$ of those with income below $130 \%$ of the poverty level are obese').

43 See Bogenschneider (2016) (explaining that high rates of wage taxation should be expected to cause negative health outcomes in society).

44 Pratt, 129 ('Public health advocates who have proposed SSB taxes have ignored such welfare losses that their proposals might cause. They assume that the consequences of enacting an SSB tax would be entirely positive, especially with respect to low-income consumers').
}

45 See e.g., Efrat and Efrat (2012), 250. 
what might be called the 'fairness issue' is beyond the scope of this paper which is concerned with the theoretical coherency of Libertarian Paternalism applied as tax policy.

\section{Behavioural Economics and Public Health}

The vast majority of the public health literature on the taxation of sugar-sweetened beverages presumes that people are not able to make good choices in respect to food. Scholars setting out to apply economic theory to health via the tax lever have referred to persons as 'idiotic', 46 'stupid', 47 'child-like', 'naï's' ${ }^{48}$ or 'lowcapacity'. ${ }^{49}$ Notably, several major law review articles likewise address the issue as analogous to dealing with an 'unruly child'. ${ }^{50}$ However, in terms of the history of taxation, Leona Helmsley may have said it best by coining the term 'little people' to describe persons that are required to pay taxes. ${ }^{51}$ In economic terms, a decision regarding food consumption may accordingly be described as 'irrational', meaning non-rational decisions made by Helmsley's 'little people'. The literature goes on to assess whether tax policy can be effective in fostering a better and more 'rational' decision by the 'low-capacity' persons. The core thesis of this paper is that such name-calling is entirely a rhetorical and non-substantive methodology that does not reflect a coherent view of 'rational' choice.

Empirical studies are mixed on the potential effectiveness of applying the 'lever' of tax policy in respect to sugar-sweetened beverages. Yet, several studies conclude that the tax incentive would only have an effect if the tax were very large in amount and the proceeds earmarked for nutritional literacy programs in low-income communities. ${ }^{52}$ The standard policy recommendation now applied to taxation is thus essentially the same as the first proposal of Thaler and Sunstein that consumers, namely poor people, are not able to make good decisions about food and beverages. In other words, those 'irrational' fools should first be taxed, and then, the proceeds of the tax should be earmarked for re-education programs. A parallel line of research focuses on the 'innumerate' poor who are unable to read nutritional labels and ostensibly to determine prices of food. ${ }^{53}$ The idea of re-education programs to

\footnotetext{
46 Camerer et al., 1211.

47 Quigley, 618.

48 Pratt, 130 (coining the term 'naif's'). Note that similar to this article Pratt offers the term to highlight an opposing policy position and not in a pejorative manner.

49 Baldwin, 840, 842 'Capacity' refers to the ability of that person to gain, receive absorb and act on information... Such individuals will possess a high ability to 'unearth' nudges, such as defaults, and to resist these. Low capacity individuals will struggle to absorb and act on even simple messages, even when disposed so to act').

50 See e.g., Yeung (2012), Efrat and Efrat at 246.

51 Hammer (1990).

52 See Alemanno and Carreno (2013).

53 Brownell et al. (2009), 1603; see also Pratt (2012), 138 ('In addition to being mindful of consumers' enjoyment of their food, public health advocates should design food tax/subsidy systems so that consumers can understand them easily and quickly. In particular, the food classification system should be understandable to the ninety million Americans who do not read above a basic level or are innumerate').
} 
reduce innumeracy in food choice are sometimes referred to as nutritional 'literacy' programs.

The second-guessing of consumer choice does not seem on its face to be a 'Libertarian' approach at all. Thaler and Sunstein have an answer to this observation. They argue that libertarian paternalism is distinguishable from raw paternalism insofar as it is concerned only with nudging, not commanding, persons toward the decision that any rational person would have made anyway. ${ }^{54}$ Of course, that choice happens to be the choice the 'parent' also recommends and where tax is levied on the wrong choice. In respect to obesity, this means that the 'rational' person would surely choose a more optimum diet if only given the opportunity to rethink their foolish beverage decision, and if confronted with better evidence and perhaps more time to mull it over. ${ }^{55}$ Thaler and Sunstein further wrote:

There is overwhelming evidence that obesity causes serious health risks, frequently leading to premature death. It is quite fantastic to suggest that everyone is choosing the optimal diet, or a diet that is preferable to what might be produced with third party interference. Of course rational people care about the taste of food, not simply about health, but the claim that Americans are choosing diets optimally would be hard to support. ${ }^{56}$

Hence, Libertarian paternalism, at least the version as proposed by Thaler and Sunstein, is essentially equivalent to the non-Libertarian raw paternalism in respect to obesity policy. And, as long as we are talking about wealthy persons that can afford to buy fresh, healthy, foods and beverages without respect to price such an approach has the potential to be internally coherent in deriving tax policy. Such wealthy persons, for some reason other than relative price, still choose not to buy such foods. This 'bad' decision obviously is one not premised on a comparison of price with the health costs. Then, and only then, is the unbound food decision presumptively 'irrational' in economic terms without further investigation of relative price and consumption preferences. However, for a person that can afford to buy only canned, unhealthy, processed, foods, then the decision-matrix is bounded by the limits of possible food purchases by prices. ${ }^{57}$ A decision made subject to the bounds of price is not properly described as economically 'irrational' without further data on relative prices to the consumer. Rizzo and Whitman refer to the Libertarian paternalist approach as a 'non-sequitor' for this reason. ${ }^{58}$ As Katherine Pratt wrote in more conciliatory terms:

\footnotetext{
54 Galizzi (2012); Galle (2013); see also Barton and Grune-Yanoff (2015).

55 See Rizzo and Whitman, 712 ('The new paternalists claim to have found policy interventions that will make targeted agents better off according to the target agents' own preferences. What they have in fact found is evidence of internal conflict in the target agents' preferences, and then they have resolved the conflict in favor of the experts' preferences').

56 Thaler and Sunstein (2003a, b), 1168.

57 Baldwin, 832 ('The proponents of nudge build on the well-established insights of cognitive psychology and behavioural economics to contend that control systems need to take on board the bounded rationality of citizens when they make daily decisions').

58 Rizzo and Whitman, 711.
} 
Public health paternalism is a much more controversial policy justification for food taxes, however. To date, public health advocates have focused only on the assumed benefits of food and soda taxes and have ignored inefficiencies and welfare losses that such taxes might cause, leaving their proposals vulnerable to economic counterarguments. ${ }^{59}$

Furthermore, a person who does not behave as an economist might expect likely does not agree that he has made an 'irrational' choice to consume a sweetened beverage as opposed to water (as Brownell has in mind). As Pratt wrote: '[M]ost naive consumers may not understand that they need help structuring their dietary decisions. ${ }^{60}$ Indeed, such persons may even affirmatively substitute from the taxed sugar beverages to high-fructose fruit juice, for example. In such an unwelcome case of disobedient behaviour, the person seems to be intentionally choosing the 'irrational' choice. ${ }^{61}$

Where behavioural economic analysis is based on non-quantitative or empirically based expectations about optimal choice without reference to either consumer preferences or relative price; this amounts to what might be called 'conjecturaleconomics'. ${ }^{62}$ Such an approach is surely not 'science'. Furthermore, there is nothing empirically 'rigorous' about conjectural economic methods applied in this fashion. The purportedly 'economic' analysis applied is intentionally designed so as not to account for 'welfare losses'. Accounting for these losses would reduce the normative impact of the proposed storyline, which otherwise is a key element of economic theory. The formal argument that consumers are just 'idiots' is, in the best case, a rhetorical argument. ${ }^{63}$ As Camerer, et al., argue: 'In a sense, behavioural economics extends the paternalistically protected category of 'idiots' to include most people, at predictable times. ${ }^{64}$ A contrary description of human choice is the following: The poor are making rational decisions albeit with significant barriers to choice and behavioural economists and others are simply misinformed (or naïve) ${ }^{65}$ about the limited bounds of decision faced by the poor in respect of food choice.

\footnotetext{
59 Pratt, 139-40.

60 Ibid, 132.

61 Baldwin (2014), 842 ('Low capacity individuals who are ill-intentioned, will, moreover, have very limited ability to adjust their behaviour so as to reject messages that they disagree with and to act in ways that are inconsistent with such messages. They will, in turn, possess poor abilities to 'unearth' nudges such as defaults, and resist these').

62 See Finkelstein, Ruhm and Kosa (2005), 244 ('Economists' first law of demand implies that a decrease in the price of food will cause consumption to increase. Moreover, if the price of calorie-dense, prepackaged, and/or prepared foods (e.g., fast food) falls faster than for less calorie dense foods (e.g., vegetables), then individuals will shift their consumption toward these cheaper alternatives').

63 Rebonato (2014), 378 ('Of course, just observing what the individual chooses is no longer a viable option, as the preference that is satisfied by the observed action may be the uninformed or irrational one').

64 Camerer et al., 1218.

65 Rizzo and Whitman, 711 ('The experts themselves have, at best, only a tenuous grip on the values of the targeted agents, which limits the direct applicability of their paternalistic theories to policy').
} 


\section{'Symmetry' in Tax Policy}

'Symmetry' is a key element of paternalistic tax policy proposals. Camerer, et al., propose that the tax system is asymmetric: 'A regulation is asymmetrically paternalistic if it creates large benefits for those who make errors, while imposing little or no harm on those who are fully rational. ${ }^{66}$ The logic is that the tax system implicitly redistributes from the 'rational' to the 'non-rational' members of society implying an asymmetry. But, this description of the tax system based on marginal statutory tax rates is flawed. The tax system in most Organisation for Economic Cooperation and Development (OECD) countries taxies primarily labor, even when the statutory rates of income taxation might be at least ostensibly progressive. In most OECD countries, roughly $85 \%$ of tax collections are derived from direct or indirect labor taxation. ${ }^{67}$ Notably, wherever and whenever Pigouvian-type taxes on 'internalities' are proposed as a matter of tax policy, the tax is always directed against the poor.

In contrast, an alternative view is that the predominant 'irrationality' in society is the stockpiling of wealth by persons with no plans to reinvest the stockpiled hoards of money into living persons as a type of resource-hoarding behaviour. ${ }^{68}$ Furthermore, such capital accumulation for the sake of accumulation is not utility-maximizing behaviour except under very strained assumptions; in fact, Charles Dickens is thought to have written his novels in response to the writings of John Malthus on this point exactly. ${ }^{69}$ Dickens clearly explains why Scrooge is not and ought not to be the norm of human economic behavior.

The targeting of the poor using Libertarian paternalist argumentation is the primary form of 'asymmetry' in tax analyses. Prior economic discussions of sugarsweetened beverage taxes that focus exclusively on proposals for taxing the poor who are taken to be cognitively biased, irrational, and inferior. As Jennifer Pomeranz wrote in respect to prior sugar-sweetened beverage tax policy proposals: 'This tax would thus not address the poor eating practices of wealthier individuals even though it is equally unhealthy for them to consume an excess amount of food. ${ }^{70}$ A revision to tax paternalism is proposed here as 'symmetric'-paternalism where the word 'symmetric' refers to applying the same logic of paternalism normally reserved for the poor to the wealthy as well.

The emphasis of Libertarian paternalism on rational choice is accordingly far different in terms of its policy implications than the proposition of Thaler and Sunstein to nudge toward rational choice. The benefits of Pigouvian taxes are

\footnotetext{
${ }^{66} \mathrm{Ibid}, 1212$.

${ }^{67}$ See OECD Revenue Statistics, 29 available at www.oecd.org/ctp/tax-policy/revenue-statistics19963726.htm; Office of Management and Budget (OMB), The Budget for Fiscal Year 2015, Historical Tables, 32-33 www.whitehouse.gov/sites/default/files/omb/budget/fy2015/assets/hist.pdf.

68 Bogenschneider and Kasper, (2016).

${ }^{69}$ Avery (2005), 19 ('One can also view many of the books of Charles Dickens as protests against Malthus point of view').

${ }^{70}$ Pomeranz, 1004.
} 
optimized when the tax on externalities can be targeted to each person, ${ }^{71}$ which also is true in respect to offsetting internality-type costs. The optimal amount of 'sin' taxes should be adjusted proportionately to take into account the internality cost to each individual person. ${ }^{72}$ As illustration, a billionaire might be expected to pay $£ 100,000$ in tax for a six-pack of soda or a pack of cigarettes to reflect the internality cost to the health of such a valuable personage.

\section{Problems in 'Rational' Choice Theory}

Thaler and Sunstein wrote: 'As far as we can tell, there is little empirical support for [the claim that people make rational decisions]. ${ }^{73}$ This represents the base claim of economics as a normative ideology where economics purports to be the study of 'rational' behaviour as defined by economic theory. However, economic behavior is in at least some cases not 'rational enough' to be studied as if it were 'rational'. Another possible conclusion is that the field of economics is flawed in its understanding of what rational human choice means or entails.

In technical economic terms, the stubbornly irrational person that insists on consuming a sugar beverage in spite of the tax levy seems to be avoiding what is referred to as a 'welfare loss' of switching to water, for example. Presumptively, at least as a matter of utility theory, the person derives a sufficient utility from the product that exceeds the health cost, thus rendering the seemingly 'bad' decision rational in economic terms. As Katherine Pratt wrote: 'Public health advocates... should acknowledge the enjoyment that people derive from eating their favourite foods. The prohibitionist, absolutist, killjoy rhetoric of some advocates is too severe for most laypeople and plays into the hands of opponents of antiobesity taxes. ${ }^{74}$ Another problem in application of Libertarian paternalism to tax policy is that the direction of causation from marginal tax levies may be counterintuitive, such as with a 'Giffen good' referring to a product where in some situations an increase in price increases the demand. ${ }^{75}$ For example, a tax levied on sugar-sweetened

\footnotetext{
71 Strnad, 1244 ('A Pigouvian tax schedule may be very complicated if the relationship of external cost to consumption is nonlinear'); see also Williams (2013/14), 164 ('In theory, we could craft millions of tiny little taxes to compensate for every 'market failure' we manage to uncover. But that's impractical, so instead we pick and choose a few sin taxes that we find especially appealing.') citing Thorndike, Tax.com (2012).

72 See Doucett (2015), 397-8 ('The most common attempt at implementing a tax policy is through a soda or junk food tax. This is a tax on an isolated, specific category of food or drink. These taxes are "modeled after the 'sin taxes' already implemented on cigarettes and alcohol" and seek to increase the price of these unhealthy foods and drinks enough to reduce consumption').

73 Thaler and Sunstein, 1168.

74 Pratt, 137.

75 See Cornelsen et al. (2014) ('[C]onsumers may still continue buying the now higher priced food but reduce the quantity of other foods they consume to continue to afford it, including healthy foods. This is known as the income effect and it is more likely to affect lower income earners as they spend a relatively greater share of their incomes on food'). Note also the possibility of the 'cross price effect'. Cornelsen, et al. at 3 ('[With the own-price effect] they are left with a decision about what to consume instead').
} 
beverages could reduce the amount of disposable income available to persons and thereby increase (not decrease) the demand for sugar.

\section{The Supposed 'Non-rationality' of the Poor in Respect to Food}

In the real world, low-income persons are, by necessity, highly price-numerate in respect to consumer goods-often more so than the wealthy! The idea that poor people as a class are price-innumerate is accordingly best-viewed as naïve; many of the poor are masters of price in respect of consumer goods including food and always have been. The poor must out of necessity carefully evaluate relative prices in the supermarket. It may come as a surprise to many researchers that one of the most popular and long-running daytime television programs in the United States (The Price is Right) deals solely with guessing prices on consumer goods, a favourite pastime of the poor! In fact, the wealthy are not as knowledgeable, entertained-by, or as sensitive to price on consumer products where the cost is de minimus in respect of income. The wealthy are thus potentially more susceptible to poor decisions in respect of consumer goods.

Decades of economic literature suggest taxes should be neutral to economic choice. In an ironic twist, Griffith and O'Connell argue that regressive taxes levied on food are most likely to change the behavior of the poor. So, this is the formal statement of a non-'neutral' tax policy by design. The non-neutrality of tax policy appears to be okay in the minds of researchers as long as the tax policy is levied on persons with less money. Griffith and O'Connell wrote:

Often lower income households are the most price sensitive, which would mean they are likely to change their behaviour most as a consequence of a price rise. To assess the overall effect of the tax and whether low or high income consumers would be affected more, we would need to set the costs imposed by the tax on consumer through higher prices against the potential health benefits arising through their changed behaviour. ${ }^{76}$

As discussed in further detail below, even if we accept Griffith and O'Connell's methodology, a sugar-sweetened beverage tax could likewise be levied on a wealthy person at a low rate without changing consumption behavior up to a relatively high threshold. By the very same logic, the amount of the sin tax policy for the wealthy should then be increased until the wealthy person responds to the incentive and decides to behave in a healthy manner for his own benefit. A discussion of whether higher tax rates on the wealthy is a good policy idea bleeds into traditional areas of tax incidence analyses; however, at least by the logic of Brownell, et al., the tax levies from the wealthy could be earmarked for re-education programs for lowerincome persons. ${ }^{77}$

\footnotetext{
76 Griffith and O'Connell (2011).

77 See Andreyeva et al. (2011), 413 ('A modest tax on sugar-sweetened beverages could both raise significant revenues and improve public health by reducing obesity. To the extent that at least some of the tax revenues get invested in obesity prevention programs, the public health benefits could be even more pronounced').
} 


\section{Other Explanations for Ostensibly Irrational Choices}

'Facts' in economics or anything else are a function of theory. Facts are not observed or known objectively or separate from the theory. And, this is partly what we call 'science', which explains why there is more to science than gathering and summarizing empirical observations. As Karl Popper explained, even such evidentiary gathering in the laboratory is a theory-driven endeavour. ${ }^{78}$

Economics is premised upon a theory of choice regarding how human beings make decisions. In most scholarly discussions of food choice, rational choice theory is immediately abandoned as it relates to the food-purchase decisions by the poor. For example, in respect of the choices of the poor, scholars often attribute causation to something within the decision-making process that leads to a miscalculation of the respective cost-benefit analysis inherent to choosing healthy foods. So, a scientist evaluating this approach ought to ask: What is the underlying theory? Is the theory consistently applied? Where is the causative element for testing? The answers are respectively: 'undisclosed', 'no' and 'missing'. All of these indicate that the economic ideas of Libertarian paternalism are not science, so there is nothing whatsoever to test in the first place. With no possibility of falsification, indeed, there is nothing that might remotely be called 'science' or 'scientific inquiry' within the methodology of Libertarian Paternalism.

In fact, there are other possible scientific explanations for an observation by economists of what they think is an 'irrational' choice in respect to food, such as the following: (1) Flawed theory of causation; (2) Mistake of 'fact' criteria within the theory; (3) Mistake of observation/counting (particularly in the social science). For example, a flawed theory seems to be the pertinent description of the state of affairs where economics does not seem to explain actual human choice in the world. Astonishingly, Thaler and Sustein begin with the purportedly flawed description of empirical economics, thus indicating the entire undertaking is non-scientific $\mathrm{ab}$ initio. A mistake of fact criteria might also be thought to occur where the 'welfare loss' criteria of economics is misapplied. A mistake of observation could be thought to occur with the econometric evaluation of what economists conclude 'probably is' in the world. ${ }^{79}$ In other words, the assessment by economists of what they think 'is' may then be used to derive the homo economicus claim of what 'ought' to be. However, none of these are developed by economic researchers in the context of rational choice theory. The question then is if economists are not engaged in 'science', then what is the 'ought'-based choice framework of Libertarian paternalism? This issue is taken up in the next section.

\footnotetext{
78 Popper (1935/2002), 90 ('[T]he theoretician must long before [experimentation] have done his work, or at least what is the most important part of his work: he must have formulated his question as sharply as possible. Thus it is he who shows the experimenter the way. But even the experimenter is not in the main engaged in making exact observations; his work, too, is largely of a theoretical kind. Theory dominates the experimental work from its initial planning up to the finishing touches in the laboratory').

79 See Rostain, 979 ('Evidence that people are not perfect utility maximizers, itself, does not create a problem for the traditional economics model. So long as human errors are random, get canceled in an aggregative analysis').
} 


\section{Problems in the Theory of Behavioural Economics}

\section{Economic Claims of 'Is' Versus 'Ought' on Food Choice}

The use of the term 'irrational' to describe suboptimal 'rational' choice means that the behavioural economist is necessarily referring to a standard held in his own mind (the 'Ought'), and not the mind of the person engaged in economic choice (the 'Is'). Economic theory is accordingly the study of the economic idea of 'ought ${ }^{80}$; whereas, econometrics is the study of the economic consensus of what 'probably is'. The study of variances from expected results may by 'psychological' insofar as the expectation exists solely in the mind of the economic researcher. The renowned economic genius, Frank Ramsey, identified a similar problem in respect to probability theory (such as expected results in dice throws). ${ }^{81}$ Since public choice theory deals with human choices in the public sphere that are unexpected, this means the given 'logic' of economics does not correspond to what economics expect to find in the world. The study of 'variances' from an idealized standard accordingly relates solely to the differences between economic theory and actual decisions in the world. Economic theory accordingly falls within the field of 'psychologism' (as defined by German philosophers in the late-nineteenth century).

Economic theory is accordingly not the study of objective economics relations actually existing in the world, but is instead the study of economists themselves, or what economists think rationality entails. As Ramsey identified, statistics (and by extension, econometrics) is not the study of what 'is' in the world; rather, statistical analysis is the study of what economists reasonably agree 'probably is' given to an acceptable degree of likelihood. The main goal of econometrics is to arrive at a consensus view of whether a set of probabilistic expectations are to be deemed reasonable. A form of certainty can thereby be achieved by proscribing back the horizons of choice to the positive version that economics creates (i.e., describing the choices of Posner's 'rational frog'). Yet, this scaling back amounts to a simplifying assumption by the researcher to achieve research results (qua certainty) in statistical analysis. Hence, via simplification, certainty is achieved by intentionally limiting the possibilities of choice; consequently, critics will then inevitably set out to reverse simplifying assumptions and to re-complicate matters. Accordingly, it is inevitable that the bounds of 'rational' choice will shift outward again at some future point as economists develop critiques of the rationality of the 'frog' and thereby further develop what is subsequently agreed to be 'rational'. Hence, economic theory represents an unapologetic form of 'psychologism' or the psychology of what economists think logical or rational decisions represent at any point in time.

A common simplifying assumption in economics is to proceed at the margin (or solely with respect to incremental changes), and thus, not by the average. This can

\footnotetext{
${ }^{80}$ Rostain, 977 ('To complement expected utility theory's account decisionmaking, rational choice theorists also adopt a view rational actors form their beliefs about the context of decisions, and specifically about how they should reason about the likelihood of uncertain events').

81 Ramsey (1978).
} 
lead to counter-intuitive tax policy recommendations, however. As David Madden explained in the context of the 'fat tax' in Ireland: 'The difficulties associated with non-marginal tax reforms have led a number of analysts to concentrate on marginal tax reforms. This approach has the advantage of not requiring estimates of individual demand and utility functions. ${ }^{82}$ Thus, any researcher who is concerned with decisions not at the margin will be automatically dissatisfied with economic research performed solely at the margin. However, in rejecting such arbitrary limitations, this thereby eliminates the possibility of certainty, and with it, the broader 'rationalized' choice. Perhaps the foremost example is where Pigouvian tax effects are described by economists as based on marginal effects only. This is akin to asking whether it is rational to push a pawn forward in the game of chess based solely on the marginal effects of that move. If that question can be answered, then the researcher should always take a step back to the prior move and evaluate that prior move. This has the practical effect of the re-introduction of uncertainty in determining the chess move or economic analysis of consumer behaviour as the case may be.

\section{Recycling 'Psychologism' as Behavioural Economics}

Libertarian paternalism is a type of psychologistic reasoning developed in part by Wilhelm Wundt. ${ }^{83}$ Much of the analysis of Libertarian paternalism matches closely to Wundt's description of psychologism now manifested in economic theory. First, Libertarian paternalism is an 'ought'-based claim; second, economics purports to describe the 'rational' in human thinking; third, behavioural economics purports to be the only way to measure how persons engage in economic choice. Therefore, rational choice theory is the logic of human choice (i.e., economic psychology). Wundt's framework has been summarized as follows:

1. Normative-prescriptive disciplines-disciplines that tell us what we ought to do-must be based upon descriptive-explanatory sciences.

2. Logic a normative-prescriptive discipline concerning human thinking.

3. There is only one science which qualifies as constituting the descriptiveexplanatory foundation for logic: empirical psychology.

Ergo, logic must be based upon psychology. ${ }^{84}$

If economics were not a form of 'psychologism' (i.e., the study of 'ought' vs. 'is') and was rather the study of what actually 'is', then public choice theory could be understood as a series of proofs that the 'rational' methodology of economics is flawed when applied to actual human behavior in the world. ${ }^{85}$ Hence, the description of Behavioural Economics as psychologism is not pejorative; rather, it should be taken as a compliment with internal validity derived from the methods of

\footnotetext{
82 Madden (2015), 106; see also Vallgarda et al. (2015).

83 Kusch (2015) citing Wundt (1910).

${ }^{84}$ Kusch (2015), Part III ('Examples of Psychologistic Reasoning').

85 Rostain, 981.
} 
psychology as opposed to economics. The alternative conclusion is that economic methods so applied to choice that is agreed to be not-'economic' is methodologically incoherent or a non-sequitor. ${ }^{86}$

\section{Hyperbolic Discounting}

Economists also set out to study the differences in individual preferences in respect of health (and money). This is the attempt to explain health outcomes by measuring the differences in preferences between groups or class of persons for future health. ${ }^{87}$ Such a Malthusian revivalist ${ }^{88}$ approach is referred to as 'hyperbolic discounting' premised on the assumption that rationality entails exponential (i.e., hyperbolic) discounting in human preferences over time. ${ }^{89}$ In general terms, hyperbolic discounting thus refers to the discount rate applied by persons on the valuation of future utility; or, the measurement of the rational tendency to value current rewards more than future rewards. ${ }^{90}$

Libertarian paternalism can then be combined with hyperbolic discounting theory to advocate the 'nudge' of persons to correct suboptimal discounting preferences in respect of health. For example, as applied to obesity, the idea is that some persons apply a higher discount rate to future health than is optimal. The higher discount rate causes the person to overvalue current food consumption at the expense of future health outcomes. The hyperbolic discounting approach thus relates to the study of the preferences of the obese/poor (as opposed to their rationality); however, the preferences of the test group are presumed to be suboptimal in relation to some other group, namely the fit or the wealthy. The advantage of such an empirical approach to testing economic ideas not (i.e., not premised on re-defining the 'rational') is that empirical studies can be undertaken to test the theory. And, the empirical results are in! ${ }^{91}$ In terms of health choice most empirical studies find that differences in discounting health do not explain health outcomes. In scientific terms, we might simply say that this hypothesis of hyperbolic discounting in respect of health outcomes has been falsified as the causal variable.

Economists next turn to the auxiliary hypothesis that poor persons may have different discounting preferences for money, if not health. The underlying idea is that the poor may not save money properly by undervaluing the need to save, thus explaining why they are poor. And, here, finally, we get a victory for economic theory. The poor do value future money less than the rich value future money. ${ }^{92}$ If we assume that saved money also generates hyperbolic returns higher than the

\footnotetext{
86 See e.g., Rizzo and Whitman, 711; Rostain, 975.

87 See e.g., Bickel, et al. (1999).

88 See Avery (2005). This article also explains Malthus' missing section on taxation as economic policy.

89 Samuelson (1935).

90 See Ainslie and Monterosso (2003).

91 Story et al., (2014), 1 ('The studies reviewed here indicate that discounting is a promising predictor of health behavior, however hyperbolic discounting is challenged as an explanation for the discrepancy between intentions and actions in health choice...').
}

92 Ibid, 12. 
discount rate for consumption, then any person that saved money would end up with exponentially more money over time. So, what does this auxiliary result mean exactly for health policy?

The economic analysis of health choice begins with the presumption that human preferences are subject to hyperbolic discounting; likewise, compound interest generates hyperbolic returns to saving. The decision to save money would then depend on the relative rate of discount to future consumption versus the rate of return on money toward future consumption. One plausible conclusion would simply be that the rich have better options to invest money and expect to or actually achieve a higher rate of return than the poor.

But, the other path so far unexplored as a matter of economic theory, is whether the decisions of the wealthy to save and not consume are rational. Thomas Stanley, in the Millionaire Next Door series, has given telling accounts of the extreme saving behaviour of the wealthy ${ }^{93}$ — query then, is this Scroogeantype behaviour rational? Or, stated in terms of hyperbolic discounting theory, what are the preferences of an ultra-wealthy person engaged in extreme saving behaviour? One explanation for extreme saving behaviour is that, whether rational or not in economic terms, the person greatly discounts current consumption thus enabling hyperbolic returns to capital in some cases. ${ }^{94}$ Thus, in terms of health policy, Libertarian paternalist theory applied to the wealthy (not just the poor) so engaged in extreme-saving would suggest that nudges or other regulation could be applied to encourage current personal health consumption for these wealthy persons who systematically underestimate the value of their own health. Several of Stanley's anecdotal examples of ultrawealthy food consumption behaviour (including Warren Buffet with very poor eating habits $)^{95}$ indicate that such persons improperly discount future health. In terms of Pigouvian tax policy (i.e. taxes levied to the extent of health internalities) the taxation of the wealthy with these types of preferences is the obvious place to start since we know the wealthy have sufficient income to make better choices if nudged by the tax system into doing so.

\section{Conclusion}

The Libertarian paternalist thesis that poor persons are 'idiotic', 'stupid', 'childlike', 'naiff's' or 'low-capacity', and therefore unable to make valid choices in respect of food is internally incoherent. The 'rational choice' framework of economics actually means that food decisions are presumptively valid even when the economic researcher might prefer a different alternative; moreover, when a researcher further claims that his or her methodology fails to predict human

\footnotetext{
93 Stanley and Danko (1996).

94 Note that Stanley only describes and measures successful outcomes, and not persons with failed investment outcomes that for whatever reason engaged in extreme saving and did not achieve a hyperbolic return from saving.

95 See Hahm, 'Warren Buffett will Not Apologize for His Junk Food Addiction', http://finance.yahoo.com/ news/warren-buffett-berkshire-hathaway-sweet-tooth-dairy-queen-coca-cola-see-s-candies-201539716.html.
} 
behaviour most of the time, then the theory is flawed and should be abandoned in favour of a better theory. And, where the Libertarian paternalist (qua economist) readily admits the theory so applied is not predictive of human behaviour most of the time, then a better theory should be readily available. We call that sort of approach to inquiry 'science'. We call a name-calling approach to inquiry directed against classes of persons 'rhetoric'. ${ }^{96}$ Tax policy based on 'rhetoric' generally results in justifications for taxes levied predominantly on workers (or the poor) as a class of persons. Of course, the vast majority of the tax base is today levied on workers at least in OECD countries. Accordingly, the claim by Camerer, et al., that tax policy is 'asymmetric' because the poor make bad choices and pass the burden to the wealthy who make good choices is plainly factual error based on misunderstanding of the composition of the tax base.

The predominant form of 'asymmetry' in respect of Libertarian paternalism is the application of the method solely to change the food choices of the poor. Without the collection of detailed data on relative prices or consumer preferences, Libertarian paternalism represents a coherent approach to tax policy only when directed against unhealthy food choices of the wealthy who are presumptively not subject to boundaries of food price. In the case of wealthy consumers, tax policy could be used as a signal to 'nudge' the person toward a better food choice based on their own preferences $^{97}$; however, in respect to low-income consumers, the tax-'nudge' may interfere with preferences and create a 'welfare loss'. Such a tax policy could also create perverse results with a 'Giffen' good, or as described by Pratt:

The combination of a food tax and a healthy food subsidy conceivably could, in theory, lead weight-conscious, physically active people to gain weight, however (as a result of spending more time on healthy meal preparation and less time exercising), so we should try to determine whether this prediction is accurate regarding active consumers. ${ }^{98}$

If the purpose of Pigouvian-type tax policy is to raise revenue and not necessarily to change behaviour, then it is conceivable that wealthy persons could be charged a high rate of excise tax to offset the internality health cost up to the price that would not change consumption behaviour.

Finally, as a matter of tax policy design, the current tax system encompasses existing forms of taxation that are already serving public policy goals. For example, wage taxes are thought to fall on immobile workers as opposed to 'mobile' capital. Many economists say this tax policy should increase economic growth (albeit without empirical evidence for the claim). ${ }^{99}$ However, since workers can only pay so many regressive taxes at once (wage taxes, gasoline taxes, fat taxes, council taxes, etc.), a coherent tax policy proposal must compare the costs and benefits of

\footnotetext{
96 See McCloskey (1983).

97 Rizzo and Whitman, 700 ('New paternalists claim that they are evaluating the observed behavior of the individual in terms of his own normative standard. This appears attractive until we realize that the individual has no unambiguous standard for the appropriate level of time discounting').

98 Pratt, 125.

99 Clausing, 460, 480.
} 
one regressive tax against another regressive tax as exclusive to each other; and not to make comparisons of a proposed tax against a status quo situation in an imaginary alien civilization where the poor do not pay any taxes. Hence, in any honest intellectual debate over economic policy, we should expect to observe preeminent economists debating the relative merit of wage taxes in comparison to sugar- sweetened beverages as possible alternatives. The absence of any inkling of such a debate in economic circles indicates the economic discourse in respect to tax policy is normative.

The potential tax policy implications of switching the underlying philosophical premise of all tax policy are also far more profound than Brownell, et al., and other public health experts have thus far acknowledged. If taxes are to be maximized based on a presumption of non-'rational' choice associated with the product without data on relative price or consumer preferences, then what other consumer choices might also be thought to be irrational and therefore subject to tax? For example, are jet-skis also a presumptively non-'rational' purchase decision under this framework? What about 12-cylinder sports cars, or small-engine aircraft? The answer to each of these questions seems to be 'yes'. In terms of particular food products, what about gout-causing foie gras consumed primarily by the wealthy? Under the approach of Brownell, et al., the taxation should be maximized to stop the wealthy from harming themselves by consuming the foie gras product. The bottom line is that the link between Libertarian Paternalism and any particular tax policy and the specific consumer items upon which the policy is to be applied, at least thus far seems to be solely the class of the person making the purchase decision. Furthermore, if taxes are to be maximized under the Brownell, et al., framework for tax policy, there is as yet no coherent reason not to set the tax at a prohibitively high level on the respective product, thus resulting in de facto prohibition with an even greater public health benefit. ${ }^{100}$ And, furthermore, if sin taxes are to be levied, is the objective of tax policy to design the tax so as to raise revenue or to deter consumption of the underlying product? Obviously, the producers of foie gras might be disappointed if the sin tax was set at a very high level (say $£ 100,000$ per serving) and this led to a decline in sales of the product.

A coherent application of Libertarian paternalist theory to tax policy indicates that sin taxes (e.g., sugar sweetened beverage taxes) are a better fit when applied against the wealthy and not the poor. This is because the wealthy are the social group that have the greater flexibility in economic decision-making (i.e., the greatest 'bounds' of choice) and most readily admit a 'bad' decision was made in respect of food choice. Absent data on the relative price of healthy foods available to the poor, or evidence related to consumer 'welfare', behavioural economics can be applied to establish only that the wealthy could be 'nudged' toward better dietary decisions. ${ }^{101}$

\footnotetext{
100 See Anderson (1997).

101 Frazao and Golan (2005), 106 ('If cost-per-calorie comparisons were useful measures of barriers to healthy eating, we would expect higher income individuals (for whom food costs should not be a barrier) to have more healthful diets than low income households. Although diet quality does increase with income levels, the improvement is slight. Basiotis et al. found that in 1999-2000, higher income households had a Healthy Eating Index of 65 (out of 100), compared with 61.7 for households below the poverty line').
} 
Finally, in terms of moving toward a coherent tax policy, several medical scholars have sagely proposed that any incremental tax levied on the poor in respect of sugar-sweetened beverages should be offset with a credit for healthy foods, such as fruits and vegetables. ${ }^{102}$ Nnoaham, et al., wrote: 'Targeted food-related taxes could be optimized by combining them with a subsidy on fruits and vegetables.' ${ }^{103}$ Of course, such proposals do not directly address the reduction in 'welfare' to lowincome consumers in the loss of beverage choice in comparison to vegetables. However, such proposals do respect poor persons as rational agents able to analyse and compare relative prices. Ironically, recognizing rationality yields an analytically-superior version of tax policy analysis in comparison to the Libertarian paternalist version of behavioural economics that starts with the presumption that consumers are 'idiots', 'fools', 'unruly children', etc.

Open Access This article is distributed under the terms of the Creative Commons Attribution 4.0 International License (http://creativecommons.org/licenses/by/4.0/), which permits unrestricted use, distribution, and reproduction in any medium, provided you give appropriate credit to the original author(s) and the source, provide a link to the Creative Commons license, and indicate if changes were made.

\section{References}

Ainslie, G., and J. Monterosso. 2003. Preferences and rational choice: New perspectives and legal implications. University of Pennsylvania Law Review 151: 825.

Alemanno, A., and I. Carreno. 2013. 'Fat Taxes' in Europe-A legal and policy analysis under EU and WTO law. European Food and Feed Law Review 2013: 97.

Amir, O., and O. Lobel. 2008. Stumble, predict, nudge: How behavioral economics informs law and policy. Columbia Law Review 108: 2098.

Anderson, G. (1997). Bureaucratic incentives and the transition from taxes to prohibition. In Shughart W II, (Ed.), Taxing choice: The predatory politics of fiscal discrimination.

Andreyeva, T., F. J. Chaloupka and K. D. Brownell. 2011. Estimating the potential of taxes on sugarsweetened beverages to reduce consumption and generate revenue. Preventive Medicine 52(6): 413-416

Avery, J. (2005). Malthuś essay on the principle of population. Available at www.learndev.org/d1/ MalthusEssay-Avery.pdf.

Baldwin, R. 2014. From regulation to behaviour change: Giving nudge the third degree. Modern Law Review 77: 831 .

Barton, A., and T. Grune-Yanoff. 2015. From libertarian paternalism to nudging - and beyond. Review of Philosophy and Psychology 6: 341.

Becker, G. 1962. Irrational behavior and economic theory. Journal of Political Economy 70: 1.

Becker, G. 1990. The economic approach to human behavior. Chicago: University of Chicago Press.

Bickel, W., A. Odum, and G. Madden. 1999. Impulsivity and cigarette smoking: Delay discounting in current, never, and ex-smokers. Psychopharmacology (Berl) 146: 447.

Bogenschneider, B. 2014. The effective tax rate of U.S. persons by income level. Tax Notes 145: 117.

Bogenschneider, B. 2016. Wage taxation and public health. Rutgers Journal of Law \& Public Policy 14: 1.

Bogenschneider, B. 2017. Sin tax as signpost in food labelling. European Food and Feed Law Review 2017: 1 .

Bogenschneider, B., and M. Kasper. 2016. The human subconscious and taxation. International Journal of Economics and Business Law 5: 8.

\footnotetext{
${ }^{102}$ See Winkler (2013); see also Cash, et al. (2005).

103 Nnoaham, et al. (2009).
} 
Brownell, K., and T. Frieden. 2009. Ounces of prevention-The public policy case for taxes on sugared beverages. New England Journal of Medicine 18: 805.

Brownell, K., T. Farley, W. Willett, B. Popkin, F. Chaloupka, J. Thompson, and D. Ludwig. 2009. The public health and economic benefits of taxing sugar-sweetened beverages. New England Journal of Medicine 361: 1599.

Brownell, K., and N. Novak. 2011. Taxation as prevention as a treatment for obesity: The case of sugar sweetened beverages. Current Pharmaceutical Design 17 (12): 1218.

Camerer, C. 2003. Regulation for conservatives: Behavioral economics and the case for "Asymmetric Paternalism". University of Pennsylvania Law Review 151: 1211.

Cash, S., D. Sunding, and D. Zilberman. 2005. Fat taxes and thin subsidies: Prices, diet, and health outcomes. Food Economics 2: 167.

Chaloupka, F. 2009. Food prices and obesity: Evidence and policy implications for taxes and subsidies. Milbank Quarterly 87: 229.

Cooter, R., and T. Ulen. 2012. Law and economics, 6th ed. London: Pearson.

Cornelsen, L., Green, R., Dangour, A., \& Smith, R. 2014. Why fat taxes won't make us thin. Journal of Public Health 37(1): 18-23.

Dolgin, J. and K. Dieterich. 2011. Weighing status: obesity, class, and health reform. Oregon Law Review 89: 1113.

Doucett, S. 2015. Fat taxing our way to a healthier world. Suffolk Transnational Law Review 38: 387.

Efrat, M. and R. Efrat. 2012. Tax policy and the obesity epidemic. Journal of Law and Health 25: 233.

Finkelstein, E., C. Zhen, J. Nonnemaker, and J. Todd. 2010. Impact of targeted beverage taxes on higherand lower-income households. Archives of Journal of Internal Medicine 170 (22): 2028.

Fleischer, V. 2015. Curb your enthusiasm for Pigovian taxes. Vanderbilt Law Review 68: 1673.

Franck, C., S. Grandi, and M. Eisenberg. 2013. Taxing junk food to counter obesity. American Journal of Public Health 103: 1949.

Frazao, E., and E. Golan. 2005. Diets high in fruit and vegetables are more expensive than diets high in fats and sugars. Evidence-Based Healthcare and Public Health 9: 104.

Finkelstein, E., C. Ruhm, and K. Kosa. 2005. Economic causes and consequences of obesity. Annual Review Public Health 26: 239.

Galle, B. 2013. Tax command... or nudge? Evaluating the new regulation. Texas Law Review 92: 837.

Galizzi, M. 2012. Label, nudge or tax? A review of health policies for risky behaviours. Journal of Public Health Research 1: 14.

Green, K. 1999. Was wittgenstein Frege's heir? Philosophical Quarterly 49 (196): 289.

Griffith, R., \& O'Connell, M. (2011). IFS Publications 5712. Available at www.ifs.org.uk/publications/ 5712.

Hammer, R. (1990). The Helmsleys: The rise and fall of Harry and Leona. New York: NAL.

Herrnstein, R., G. Loewenstein, D. Prelec, and W. Vaughan Jr. 1993. Utility maximization and melioration: Internalities in individual choice. Journal of Behavioral Decision Making 6: 149.

Kelsen, H. (1962). The pure theory of law (2nd Ed.), Knight, tr., Berkeley: University of California Press.

Kusch, M. (2015). Stanford Encyclopedia of Philosophy . https://plato.stanford.edu/entries/wilhelmwundt/

Leiter, B. 1992. Intellectual voyeurism in legal scholarship. Yale Journal of Law and Humanities 4: 79.

Madden, D. 2015. The poverty effects of a 'fat tax' in Ireland.Health Economics 24: 104.

Mankiw, N.G. 2009. Smart taxes: An open invitation to join the pigou club. Eastern Economic Journal 35: 14.

Masur, J., and E. Posner. 2015. Toward a Pigouvian state. University of Pennsylvania Law Review 164: 93.

McCloskey, D. 1983. The rhetoric of economics. Journal of Economic Literature 21: 513.

Min, H. 2013. Large-sized soda ban as an alternative to soda tax. Cornell Journal of Law and Public Policy 23: 187.

Neistat, C. (2012). Soda ban explained. New York Times. Available at www.nytimes.com/2012/09/10/ opinion/soda-ban-explained.html.

Nnoaham, K., G. Sacks, M. Rayner, O. Mytton, and A. Gray. 2009. Modelling income group differences in the health and economic impacts of targeted food taxes and subsidies. International Journal of Epidemiology 338: 1324.

Ogden, C., Lamb, M., Carroll, M., \& Flegal, K. (2010). Obesity and socioeconomic status in adults: United States, 2005-2008. NCHS Data Brief, No. 50, 2.

Posner, R, (2003). Economic analysis of law, (6th Ed.). New York: Aspen. 
Pratt, K. 2012. A constructive critique of public health arguments for antiobesity soda taxes and food taxes. Tulane Law Review 87: 73.

Quigley, M. 2013. Nudging for health: On public policy and designing choice architecture. Medical Law Review 21: 588.

Ramsey, F. P. 1978. Truth and Probability. In Foundations: Essays in philosophy, logic, mathematics and economics, ed. D. H. Mellor. London: Routledge.

Rebonato, R. 2014. A critical assessment of libertarian paternalism. Journal of Consumer Policy 37: 357.

Rizzo, M., and D. Whitman. 2009. Little brother is watching you: New paternalism on the slippery slopes. Arizona Law Review 51: 685.

Rostain, T. 2000. Educating homo economicus: Cautionary notes on the new behavioral law and economics movement. Law and Society Review 34(4): 973-1006.

Samuelson, P. 1935. A note on the measurement of utility. Review of Economic Studies 4: 155.

Sandmo, A. 1976. Direct versus indirect Pigouvian taxation. European Economic Review 7: 337.

Schiavone, G., G. Anna, M. Mameli, V. Rebba, and G. Boniolo. 2014. Libertarian paternalism and health care policy: A deliberative proposal. Medical Health Care and Philosophy 17: 103.

Sen, A. 1977. Rational fools: A critique of the behavioral foundations of economic theory. Philosophy \& Public Affairs 6: 317.

Shughart, II, W., (Ed.) (1997). Taxing choice: The predatory politics of fiscal discrimination.

Simon, H. 1983. Reason in human affairs. Palo Alto: Stanford University Press.

Stanley, T., \& Danko, W. (1996). The millionaire next door: The surprising secrets of America's wealthy. New York: Pocket Books.

Story, G., I. Vlaev, B. Seymour, A. Darzi, and R. Dolan. 2014. Does temporal discounting explain unhealthy behavior? A systematic review and reinforcement learning perspective. Frontiers in Behavioral Neuroscience 8: 1.

Strnad, J. 2005. Conceptualizing the 'Fat Tax': The role of food taxes in developed economies. Southern California Law Review 78: 1221.

Thaler, R. (1991). Quasi-Rational Economics. New York: Russell Sage Foundation.

Thaler, R., and C. Sunstein. 2003a. Libertarian paternalism. American Economic Review 93: 175.

Thaler, R., and C. Sunstein. 2003b. Libertarian paternalism is not an oxymoron. University of Chicago Law Review 70: 1159.

Ulen, T. (1999). Rational choice theory in law and economics. In Encyclopedia of law and economics. http://reference.findlaw.com/lawandeconomics/0710-rational-choice-theory-in-law-and-economics. pdf.

Vallgarda, S., L. Holm, and J. Jensen. 2015. The Danish tax on saturated fat: why it did not survive. European Journal of Clinical Nutrition 69: 223.

Veetil, V. 2011. Libertarian paternalism is an oxymoron: An essay in defence of liberty. European Journal of Law and Economics 31: 321.

Wandel, M. 1997. Food labelling from a consumer perspective. British Food Journal 99: 212.

Williams, R. (2013/2014). How growing legislation geared towards restriction America's waist lines is restricting consume choice. University of Miami Business Law Review 22,145.

Winkler, J. 2013. Lowering the price of "Good" foods would be better than taxing 'Bad' foods in reducing obesity. BMJ 2013: 347 .

Wundt, W. (1910). Psychologismus und Logizismus, in W. Wundt. Kleine Schriften, (Vol. 1, 511-634) (Engelmann).

Yeung, K. 2012. Nudge as fudge. Modern Law Review 75: 122. 